\title{
DESTRUCTION OF PASTURES BY PARAQUAT AS A SUBSTITUTE FOR PLOUGHING
}

\author{
By A. E. M. HOOD, H. R. JAMESON and R. COTTERELL. \\ Imperial Chemical Industries, Ltd., Billingham Division, Jealott's Hill Research Station, \\ Bracknell, Berkshire
}

$P^{A}$ ARAQUA' (1, $1^{\prime}$-dimethyl-4,4'-bipyridylium dichloride) is very active against graminaceous spocies ${ }^{1,2}$. Because it is rapidly adsorbed by all but tho sandiest of soils, and thereby inactivated, it can be used for killing grasses in pastures which may be re-sown immediately without ploughing ${ }^{3}$.

To test the uso of paraquat for killing swards prior to growing arable crops, two field experiments were carried out at Joalott's Hill. One was permanent pasture followed by winter wheat sown in autumn 1961 ; the other was threeyear ley followed by spring wheat sown in 1962 .

Experiment 1. On perennial ryograss (Lolium perenne) dominant permanent pasture, the three main treatments were paraquat (at $3 \mathrm{lb}$. ion per acre in 24 gallons wator containing $0 \cdot 1$ per cent 'Agral' 90) applied on September' 19, a similar treatment followed by ploughing on October 7 and a no chemical treatment ploughed on September 12.

On October 12, Hybrid 46 winter whoat was sod-seeded on the first treatment and drilled on the other two troatments.

The three main treatments were duplicated in random. izod blocks and each plot was split into four sub-plots, each of 0.016 acre, for nitrogen manuring of the wheat in the spring.

Paraquat completely killed all foliage within seven days. Wild white clover (Trifolium repens) and some broad-leaved weeds recovered but were controlled by 'Mothoxone' $C$ spraying in the spring. Only a few grass plants, mainly meadow foxtail (Alopecurus pratensis), rough-stalked meadow grass (Poa trivialis), bent (Agrostis spp.) and perennial ryegrass, re-appeared on the sprayed/ sod-seeded and the no spray/ploughed plots. The plots sprayed before ploughing remained virtually free of woed grasses throughout.

The season was particularly favourable to winter wheat and the rich soil produced outstanding yields with no response to nitrogen fertilizer (Table 1). The sod-seeding treatment was outyielded significantly by both other treatments but still gave a highly satisfactory yield. The seeder used had blunt hoe-type coulters which tore up the turf, made rough furrows and caused patchy establishment.

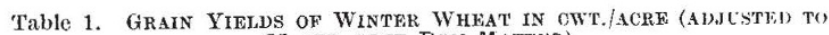
85 PER CENT DRY MATTER)

$$
\begin{aligned}
& \text { (1) Sprayed/sod-seeded } \\
& \text { (2) Sprayed/ploughed and drilled } \\
& \text { Not sprayed/ploughed and drilled } \\
& \text { Significant difference }(P=0 \cdot 05)
\end{aligned}
$$

$$
\begin{array}{r}
55 \cdot 4 \\
60 \cdot 7 \\
58 \cdot 3 \\
2 \cdot 9
\end{array}
$$

Experiment 2. On timothy (Phleum pratense)/moadow fescue (Festuca pratensis)/white clover ley, the throe main treatments wore paraquat (as in Exp. 1) on February 19. sod-seoded with 'Jufy I' spring wheat on February 20, paraquat (as in Exp. 1) on February 19, sod-seeded with the same variety on March 13 and no chemical treatment ploughed on February 6 and drilled with the same variety on March 13.

The three main treatmonts, duplicated in randomized blocks, wore each split into three sub-plots of 0.017 acre for nitrogen manuring of wheat in the seed-bod.

All foliage was killed by paraquat within about ten days. White clover and somo broad-leaved weeds re-grew, but were controlled by 'Methoxone' Extrat spraying.

Germination and brairding of wheat following the February sod-seeding were delayed by cold weather throughout February and March and so any advantage from oarly sowing in this season was probably less than would be expectod in more normal seasons. Final numbers of seedlings on the February or March sod-seeded plots were only about 60 per cent of those on the cultivater plots, possibly due to inadequate tilth in the slit-like furrows made by the disk coulters on the sod-seeder used (which was different from that used in Exp. 1) and to depredations by slugs and other soil pests.

Paraquat killed sown grass species, but had only a tomporary effoct on couch (Agropyron repens), which re-grew over large areas and competed severely with the erop. Ploughing, on the other hand, reduced couch infestation considerably.

Ploughing and drilling in March outyielded sod-seeding at all lovels of nitrogen fertilizer application and was also suporior to February sod-seeding at 0 and 60 but not at 90 units nitrogen/acre, at which level an inexplicable depression in yield occurred on the ploughed plots (Table 2).

Table: 2. GRAIN YIELUS OF 'JUHY I' SPRING WHEAT IN CWT./ACRE (ADJUSTED TO 85 PER CENT IRY MATTER)

(1) Sprayed/sod-seeded February

(2) Sprayed/sod-seeded March

Significant difference $(P=0 \cdot 05)$

\begin{tabular}{ccc}
\multicolumn{3}{c}{ Units fertilizer N/acre } \\
0 & 60 & 90 \\
$18 \cdot 7$ & $28 \cdot 9$ & $31 \cdot 4$ \\
$17 \cdot 2$ & $26 \cdot 8$ & $26 \cdot 2$ \\
$27 \cdot 8$ & $33 \cdot 0$ & $29 \cdot 8$ \\
\hline & $2 \cdot 0$ &
\end{tabular}

Sod-seeding was markedly inferior to conventional practice at the no nitrogon fertilizer-level: this was thought to be due to the offects of competing couch grass particularly in the absence of fertilizer nitrogen rather than to inadequate rolease of mineralized nitrogen from the uncultivated, dead turf. The advantage from ploughing and drilling over sod-seeding declined with increasing nitrogen rato.

These experiments confirm the suggestion of Arnott and Clement ${ }^{4}$ that satisfactory crops may be grown in pastures which, instead of being ploughed and cultivated, havo been destroyed by herbicidal sprays; they also point to such practical probloms as the design of an efficient coulter for sod-seeding and the control of couch grass and of various soil pests, including slugs, which seem to thrive in unploughed land. Nevertheless, the results of these first oxperimonts are promising for this new technique. As nothing is yot known about the effect of repeated sod-seeding on soil and crops, the present work is being continued. Further experimentation is required to assess the goneral applicability of this technique in agricultural practice.

${ }^{1}$ Cronshey, J. 1. H., Weed Res., 1, 1, 68 (1961).

${ }^{2}$ Jeater. R. S. L., and Mellvenny, H. C., Proc. Fifth Brit. Weed Control Conf., $1,311(1960)$.

${ }^{3}$ Jones, I., J. Brit. Grassl. Soc., 17, 1, 85 (1962).

${ }^{4}$ Arnott, R. A., and Clement, C. R., Nature, 195, 1277 (1962). 